\title{
Digital Taxes for Sustainable Development?
}

\author{
Whether digital or not, a fundamental paradigm \\ shift in international tax policy is overdue in order \\ to ensure adequate taxation of multinational \\ corporations. The revenues lost through tax \\ avoidance are urgently needed for investments \\ in a socio-ecological transformation. \\ By Sarah Ganter
}

$\mathbf{P}$ ublic coffers can only provide quality public services and invest in education, health, and public infrastructure if they are adequately resourced. The importance of this has once again been dramatically demonstrated to the world by the Covid-19 pandemic. But it is not only crisis management and response that cost money. Achieving sustainable development goals and transforming our economic and social systems towards less energy-intensive and lower-emission forms of production, consumption, and mobility in the course of a socioecological transformation poses enormous financial challenges for the global community. The question of how increased taxation of the rapidly growing digital economy could generate additional tax revenue for the necessary structural change or have an ecological steering effect in the sense of favouring more sustainable digital business models through taxation is therefore discussed again and again.

As early as the 1990 s, there were considerations to impose a global tax on the then new digital forms of communication in order to finance sustainable development. Under such a "bit tax", as proposed in the 1999 United Nations Human Development Report, users would pay one US cent for 10 megabytes of email volume. Given the worldwide e-mail boom, it was calculated that the total revenue would amount to a "substantial" sum (UNDP 1999). With an estimated global data volume of 175 zettabytes in 2025 (Reinsel et al. 2018), the coffers of the United Nations would be well-filled today. However, it is also possible that the decelerating effect of this tax would have taken digitalisation down a completely different path.

\section{A tax system from the analogue world}

Such a global tax did not materialise. A lot of money is at stake in tax policy, and changes to the regulatory framework affect the national sovereignty of states. This makes it particularly difficult to bring about urgently needed reforms of the international tax system. The latter will soon celebrate its centenary: In the 1920s, the League of Nations, as the predecessor organisation of the United Nations, dealt with the issue of taxation of companies operating in several states. The aim was to find a way to prevent double taxation. Already then, the interests of the countries in which multinationals are based (countries of residence) and those in which income is generated (source countries) were diametrically opposed (Rixen 2007). The resulting compromise linked the right to taxation to the existence of a physical permanent establishment. The individual branches of multinationals should be treated as independent companies and the profit should be divided proportionately between the states for taxation using the so-called arm's length principle. The intra-company exchange of goods and services should be carried out using transfer prices, as is the case with independent companies.

Over the last hundred years and in the course of globalisation, the international financial system has become increasingly convoluted. The tax rules created at the beginning of the 20th century no longer meet the needs of today's complexity. Multinational corporations and wealthy individuals are taking advantage of the regulatory vacuum. They cleverly shift profits and assets to where they are spared from the grasp of tax authorities. This practice has been taken to extremes in recent years by companies with digital business models that can also generate profits in a country independently of their physical presence. The fact that the large multinational tech corporations in particular are enjoying huge growth on the one hand, while at the same time largely shirking their responsibility in financing the common good, is causing growing resentment among the global public and highlights the urgency of the need for international regulation. The action by the EU competition authorities against Apple's tax deal with the Irish government caused a stir in 2016. Thanks to special tax arrangements, in 2014 the group had paid only $0.005 \%$ instead of the otherwise usual $12.5 \%$ of Irish corporate taxes. The EU Commission ordered Apple to pay an additional 13 billion euros (The Guardian 2016). The question of whether these practices actually violated applicable law and whether a corresponding repayment claim is justified remains a point of contention. The EU Commission appealed a court ruling in favour of Apple in 2020. This is because many of the tax avoidance practices of the big tech companies are in a legal grey area and even if they run counter to a widely shared notion of justice, illegality is diffi- 


\section{"Tax avoidance of large digital corporations exposed the existing weaknesses of the taxation of multinational companies."}

cult to prove. Google parent Alphabet, for example, reported a profit of almost 20 billion in Bermuda in 2017. The tax arrangement that became known as the "Double Irish with a Dutch Sandwich" allowed the company to shift the income of a Dutch subsidiary via Ireland to its tax domicile in Bermuda with impunity, even though the company was registered in Ireland (Der Spiegel 2019). Once again, there were calls for a digital tax.

\section{Call for a paradigm shift}

The tax avoidance practices of the large digital corporations exposed the already existing weaknesses of the taxation of multinational companies. Even previously, the arm's length principle system provided companies with traditional business models with many opportunities for "tax optimisation" by setting transfer prices between the individual business divisions. This is because it is difficult to objectively quantify which part of value creation takes place at which location along transnational production chains. In 2015, the Independent Commission for the Reform of International Corporate Taxation (ICRICT) was launched by a network of civil society organisations. It argues that a fundamental break with the principles established a hundred years ago is necessary for the international tax system to meet the needs of today's global world economy. The ICRICT Commission, which includes prominent economists from the Global South and North, proposed in its initial declaration that multinationals should no longer be treated as affiliated single enterprises for tax purposes. Instead, they should be considered as a whole and be subject to unitary taxation. This takes into account the global profits of a company and allocates taxation rights according to a formula between the countries in which the company is economically active. This formula could include factors such as sales or number of employees. In addition, a global minimum tax should counteract the international competition for lower taxes (ICRICT 2015). According to the Commission, such a reform would take the wind out of the sails of tax avoidance practices and, in the interests of greater global tax justice, would provide higher tax revenues for the countries of the Global South in particular. To implement these reforms, the Commission proposed the creation of an international tax authority at the United Nations, a UN Tax Body with universal membership.

\section{The European interim solution}

In the area of tension between countries of residence and source countries, the less location-bound value creation of the digital economy has shifted the international constellation of interests. Whereas until now it was mainly the countries of the Global South that were on the losing side of the system as source countries, the new tech companies have given European countries in particular first-hand experience of what it means when companies have a large number of users but no corresponding physical presence in the country. Since as early as 2011, there have been efforts in the European Union to create a uniform system for the taxation of multinational corporations with the so-called Common Consolidated Corporate Tax Base (CCCTB), which was not dissimilar to the idea of unitary taxation and a formulaic approach. The initiative failed due to opposition from Ireland and the UK. With its proposal for a "Fair Taxation of the Digital Economy", in early 2018 the EU Commission put forward two new reform approaches for discussion that directly targeted digital business models. The first proposal for a common reform of the EU corporate tax rules for digital activities described a virtual permanent establishment of digital platforms as complementary to the conventional physical permanent establishment. A number of criteria would have to be met, such as annual revenues of more than seven million euros and more than 100,000 users, as well as more than 3,000 business contracts for digital services in a member state. The second proposal was intended as a transitional solution until a more comprehensive reform came into force. An interim tax should cover income from activities where users are central to value creation. This includes revenue from online advertising space, digital brokerage and the sale of data and user-provided information. To protect smaller companies, a corresponding tax rate of three percent on digital services should only apply to global sales exceeding 750 million euros per year (European Commission 2018). But the initiative failed to achieve the necessary unanimity in the Council of the European Union. The fact that even among the EU member states there are countries that have a tax haven character does not make it any easier to reach a consensus. This is one reason why the EU Commission wants to gradually move to majority voting in tax matters by 2025 (European Commission 2019).

\section{The OECD Inclusive Framework}

The venue for the international reform debate beyond the European level has so far been the Organisation for Economic Co-operation and Development (OECD), in which the rich in- 
dustrialised countries are organised. A large-scale project to combat base erosion and profit shifting (BEPS) already cleared up a number of weaknesses of the previous system but did not fundamentally question its principles. Here, too, the discussion about adequate taxation of the digital economy injected new momentum into the negotiation process. In 2018, the OECD promised to find solutions for taxing the digital economy by the end of 2020 in a new edition of the BEPS project. This time, non-OECD countries were invited to participate in the negotiations. Representatives from over 135 countries are discussing new rules for international taxation in the so-called Inclusive Framework on BEPS. Even if digital business models were the impetus, the point is not to formulate a special regime for the digital economy, but to formulate solutions that put a stop to tax avoidance by multinational corporations in a globalised and increasingly digitalised world. The subject of the negotiations is a new international regulatory framework in two pillars.

The first pillar deals with the issue of a global redistribution of taxation rights and the creation of a new starting point for taxation beyond the physical permanent establishment. This would give source countries more taxation rights. Low- and middle-income countries tend to be market countries, which is why a comprehensive redistribution of taxation rights would benefit the countries of the Global South. But since profits from tax havens would be redistributed, in the end everyone would benefit from such a reform. Nevertheless, more export-oriented countries like Germany fear the loss of tax revenues. As requested by the ICRICT Commission, the OECD proposal also provides for a formulary apportionment of profits. Yet while ICRICT wants to apply it to the global profits of a company, the OECD draft distinguishes between so-called routine and residual profits, which is the profit that remains after deducting the cost of capital, and only makes part of it the subject of a formulary apportionment. However, the international taxation of routine profits is to largely proceed as before via the arm's length principle. In a statement on the negotiations, the ICRICT Commission criticises the artificial division into routine and residual profits and points out that the retention of the arm's length principle for routine profits would perpetuate the weaknesses of the old system (ICRICT 2019a).

The second pillar aims to curb the international competition for lower taxes by setting a global minimum effective tax rate. How exactly this should look like in practice is still being discussed. The OECD proposal provides two instruments to prevent companies from shifting their profits to a low-tax location. If a company subsidiary is taxed below the minimum tax rate in the country where it is based, the difference can be levied in the country where the parent company is based. This would remove the incentive for lower taxation. A second instrument has a complementary effect and taxes profits that are shifted within affiliated companies to another country if the destination country does not tax them at an appropriate level (Becker/Englisch 2019). The ICRICT Commission also favours such a global minimum tax rate but sets it at $25 \%$, twice

\section{"A fundamental paradigm shift in international tax policy is needed to ensure adequate taxation of multinational corporations."}

as high as discussed in the negotiations. A lower tax rate, ICRICT argues, would disadvantage smaller companies that pay the regular tax rates, which are only slightly below $25 \%$ on average in the OECD. Developing countries, which often have a higher rate and are also particularly dependent on tax payments of multinational corporations, would be even more affected (ICRICT 2019b). It is also important that the question of who comes first in taxation is not decided in favour of the countries of residence.

\section{Growing pressure to act for a multilateral solution}

As tax avoidance strategies exploit the blind spots of the existing system, there is little reliable data on the sums lost to public coffers. During the OECD process, multinational corporations were obliged to report their profit distribution to the tax authorities on a country-by-country basis. The question of whether these reports should be publicly accessible (public country-by-country reporting) to create real transparency is a recurring subject of political discussion, also in the European Union. Country-specific data were published by the OECD for the first time in mid-2020. With this as a basis, the civil society Tax Justice Network (TJN) calculated that the global loss of revenue due to tax avoidance by multinational corporations and wealthy individuals totals more than 427 billion US dollars per year. 245 billion of this is due to corporate tax avoidance. Against the backdrop of the Covid-19 pandemic, the State of Tax Justice report in which the figures were published calculates that the total could pay the annual salaries of more than 34 million nurses (Tax Justice Network 2020). Especially the countries of the Global South are dependent on the tax payments of multinational corporations. In the wake of the Covid-19 crisis, the pressure to reform has increased further. While the EU and OECD are struggling to find solutions, the UN Committee of Experts on Tax Matters presented a proposal in spring 2020 on how the taxation of digital services could be included in bilateral tax treaties (UN Expert Committee on Tax 2020). 


\section{"International tax policy is about weighing national self-interests against a global perspective of justice."}

\section{Time for a UN Tax Body}

Digital or not, a fundamental paradigm shift in international tax policy is needed to ensure adequate taxation of multinational corporations. The lost tax revenues are urgently needed to finance efforts to overcome the crisis and to invest in a socioecological transformation towards a more sustainable global development model. But despite intensive efforts, it has not been possible to bring the OECD negotiations to a conclusion by the end of 2020. The USA withdrew from the process indefinitely in the middle of the same year. It remains to be seen what course the Biden administration will take. Several countries have already announced unilateral measures if no agreement is reached by mid-2021, and the EU is also continuing to discuss a digital service tax as a transitional solution. This increases the pressure on international negotiations, but carries the risk of tax and trade conflicts and ultimately does not provide a sustainable solution. The US announced only recently that it will impose $25 \%$ tariffs on imports of French handbags and cosmetics from January 2021 in response to the French digital tax. Not even multinational corporations are interested in further fragmentation of the international tax system and the associated legal uncertainty. As with other multilateral challenges, international tax policy is also about weighing national self-interests against a global perspective of justice. Civil society organisations and countries of the Global South have therefore been calling for years for the United Nations to become the venue for the reform negotiations by creating an international UN Tax Body with universal membership, so that the countries of the Global South can participate in the process on an equal footing (Ryding 2020). Maybe now would be the right time for it.

\section{References}

Becker, J./Englisch, J. (2019): Internationale Mindestbesteuerung von Unternehmen. In: Wirtschaftsdienst 2019/9: 642-649.

Der Spiegel (2019): Google schleust 20 Milliarden Euro aus Europa auf die Bermudas. www.spiegel.de/wirtschaft/unternehmen/google-schleust20-milliarden-euro-auf-die-bermudas-a-1246379.html
European Commission (2018): Fair Taxation of the Digital Economy. https://ec.europa.eu/taxation_customs/business/company-tax/fairtaxation-digital-economy_en

European Commission (2019): Commission launches debate on a gradual transition to more efficient and democratic decision-making in EU tax policy. https://ec.europa.eu/commission/presscorner/detail/en/ IP_19_225

ICRICT (2015): ICRICT Declaration. https://www.icrict.com/icrictdocumentsthe-declaration

ICRICT (2019a): ICRICT response to the OECD Consultation on the Secretariat Proposal for a "Unified Approach" under Pillar One. https://www.icrict.com/icrict-in-thenews/2019/11/20/responses-to-oecdpillar-one-proposal

ICRICT (2019b): ICRICT response to the OECD Consultation on Global Anti-Base Erosion Proposal ("GloBE")-Pillar Two. www.icrict.com/icrictdocuments-icrict-response-to-the-oecd-consultation-on-global-anti-baseerosion-proposal

Reinsel, D./Gantz, J./Rydning, J. (2018): The Digitization of the WorldFrom Edge to Core. An IDC White Paper. https://resources.moredirect.com/ white-papers/idc-report-the-digitization-of-the-world-from-edge-to-core

Rixen, T. (2007): Das Doppelbesteuerungsregime als institutionelle Grundlage des internationalen Steuerwettbewerbs. In: Kellermann, C./Zitzler, J. (eds.): Steuern im europäischen Wettbewerb. Unterbieten oder gemeinsam gestalten? Friedrich-Ebert-Stiftung. 6-14.

Ryding, T. (2020): An intergovernmental UN tax commission - why we need it and how we can get it. https://www.eurodad.org/globaltaxbody

Tax Justice Network (2020): The State of Tax Justice 2020: Tax Justice in the time of COVID-19. https://www.taxjustice.net/reports/the-state-of-taxjustice-2020/

The Guardian (2016): Apple ordered to pay $€ 13$ bn after EU rules Ireland broke state aid laws. https://www.theguardian.com/business/2016/ aug/30/apple-pay-back-taxes-eu-ruling-ireland-state-aid

UN Expert Committee on Tax (2020): Tax Treatment of Payments for Digital Services. www.un.org/development/desa/financing/what-we-do/ ECOSOC/tax-committee/tax-committee-home

UNDP (1999): The Human Development Report. http://hdr.undp.org/en/ content/human-development-report-1999 